\title{
White theology in dialogue with Black Theology: Exploring the contribution of Klippies Kritzinger
}

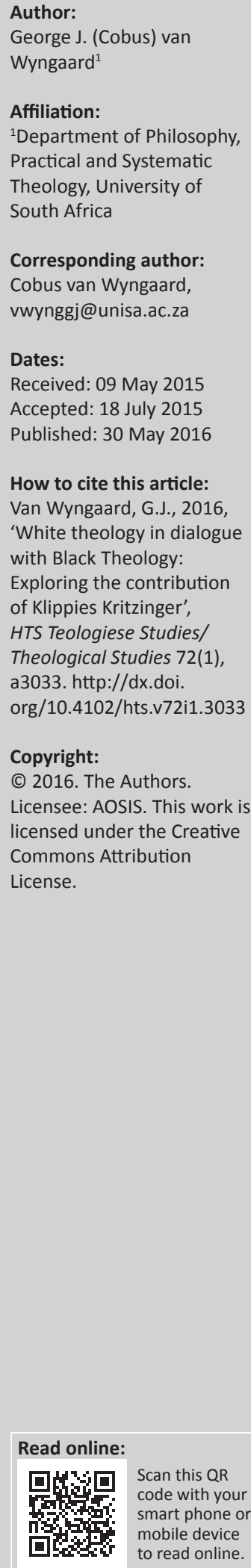

This article explores the contribution of South African missiologist and theologian Klippies Kritzinger to a critical and anti-racist white theology. It analyses his academic work in response to Black Consciousness and Black Theology from publications during his doctoral studies, throughout the transition to democracy and into the present, where this theme remains a constant presence in his work. The article explores his use of liberation, conversation and re-evangelisation in constructing a white response to Black Theology and a suggested ministry to the white community. In analysing his contribution various models of contextual theology, in particular that of Steven Bevans, are used in order to position Kritzinger and illuminate Kritzinger's approach. Bevans' praxis, counter-cultural and translation models are used to emphasize different aspects of Kritzinger's theology for liberating whiteness.

\section{Introduction ${ }^{1}$}

This article explores the contribution of Klippies Kritzinger, a South African missiologist and theologian, to a white critical and anti-racist theology. As will be pointed out below, this emphasis has been central to Kritzinger's academic work since his doctoral studies (completed in 1988) but has not been examined in detail, in spite of a Festschrift published in 2010 examining various aspects of his work. ${ }^{2}$ It is not that Kritzinger's work in Black Theology has been ignored, ${ }^{3}$ but his particular attempt at working on a theology for the white community has received scant attention. The most visible reflection on this aspect of his work appears in Transforming Mission, where David Bosch points to Kritzinger's work as an example of the challenge of liberation to the non-poor. However, this is a mere passing reference, and as a general example of the challenge to the non-poor, Kritzinger's specific work on the challenge to white Christians is not mentioned (Bosch 2004:429). This article will explore this particular aspect of Kritzinger's work.

Such an exploration will be done against the background of two other conversations: on the one hand a contemporary public and academic debate on race and whiteness in South Africa that calls for a responsible participation by white theologians and those who are white and, on the other hand, similar attempts by white theologians in other parts of the English-speaking world to critically engage the whiteness of theology and to seek a theology that challenges whiteness. Against the background of these conversations, Kritzinger's contribution provides a vital starting point for theologically exploring whiteness in South Africa.

With regard to the second conversation, a few brief comments will form part of an introduction to the argument. If there is an indication of a growing conscious theological engagement of whiteness by white theologians, particularly since the turn of the century, ${ }^{4}$ then it remains an exception to the general silence of white theologians concerning race and a lack of conscious and critical engagement with their own whiteness and its implication for theology.

The introduction to a recent book chapter titled 'White Practical Theology' illustrates this point.

When the process of writing Opening the field of Practical Theology was started it did not include a chapter on white practical theology. The book included chapters on practical theology 1.An earlier version of this article was initially presented as a paper at the 2014 meeting of the American Society of Missiology. 2.In this Festschrift, the only explicit references to Kritzinger's work on whiteness were by Banda (2009:122) and Nel (2009:140). 3.See, for example, Saayman (2009:12), Vellem (2007:115) or the extensive use of Kritzinger's analysis of Black Theology in Tenai (2010). 4.See books dedicated to the question: Perkinson (2004), Harvey, Case and Gorsline (2004), Cassidy and Mikulich (2007), Budden (2009) and Harvey (2014). 
from African American, Asian, US Latino/a and various other particular social and ecclesial locations, but

assumed that white racialization was the norm of the discipline, and the 'other' ethnic or racial groups needed to tell the story of how their cultural norms and racialized identity inflected the universalized (white) field of practical theology. (Beaudoin \& Turpin 2014:251)

However, the final inclusion of the chapter on white practical theology also reflects a growing concern with the silence on whiteness in theology and serves as an example of an attempt at breaking this silence.

This article starts by examining the challenge of Black Theology and how Kritzinger responded to this challenge with his particular white theology. This section mainly focuses on an overview of his work, from just before he completed his doctoral dissertation to date, by looking at his use of three theological metaphors. The second part of the article situates Kritzinger's white theology as a particular contextual theology by drawing primarily on Stephen Bevans's (2002) Models of Contextual Theology. Finally some brief comments are made on possible further questions beyond the work of Kritzinger.

\section{The challenge of Black Theology and Kritzinger's white theology}

It is perhaps most appropriate to find the origin of Kritzinger's work in a personal encounter, a friendship that challenged him, before positioning it within an academic debate.

Kritzinger (2001) describes an incident in 1986 as the most significant moment of his studies in the Netherlands:

[Dr] Mpho [Ntoane] enquired about my research and then asked whether I was giving the same attention to my own white history and identity as I was giving to the struggle of black Christians with their black history and identity. I had to admit that I was not, and realised that I had to add a chapter on white responses to Black Theology and to situate my whole study as a particular type of white response to it. (p. 247)

The shift towards situating his study, and later work, as a particular white response is of the utmost significance. Out of this conversation he
... became convinced that the only credible way to pursue my theological vision was to come to terms with my whiteness, religiously as a Reformed Christian, culturally as an Afrikaner, economically as a member of the privileged middle class, and politically as a person who was legally allowed to vote under apartheid. (Kritzinger 2001:247)

This is not simply emphasising the liberation of black South Africans, although it cannot be understood if disconnected from Black Theology of liberation. Kritzinger writes that

[a] self-effacing concern of white people to achieve only black liberation cannot escape the trap of paternalism, since it contains the tacit assumption that white people do not need to be liberated. (emphasis in original, Kritzinger 1988:296)
In recent decades James Perkinson, a North American theologian and inner-city activist, has been described as the white theologian who has given the most sustained attention to a critical theological analysis of whiteness. James Cone (2012:94) describes Perkinson as 'the only white theologian who has critically engaged white supremacy politically and theologically'. Perkinson (2004:40) explains the challenge to white theologians: 'What is needed is not merely evaluation of Black Theology, but the articulation of a white theology that is itself contextual and thus accountable'. This is very similar to Kritzinger's (1988) description of his own work:

My whole study ... is an attempt at mediating this black challenge to white Christianity, and to 'catch the boomerang' by working out a theology for a liberating ministry in the white community. (p. 272)

Kritzinger situates his entire study, and large sections of his later work, as a particular white response to Black Theology. To put it in another way, the challenge that Kritzinger picks up from Black theologians is to consciously give attention to his own history and identity as white in the midst of a racialised society. Key to this is that Kritzinger allows Black theologians to become his primary interlocutors in an attempt at analysing whiteness.

\section{Analysing whiteness}

I will start with a brief overview of Kritzinger's description of whiteness, since this provides the background for his conscious white theology.

Whiteness, while globally connected, is constructed locally, in each national regime (Garner 2007:1). This implies that while international descriptions of whiteness can be helpful, it is important to describe whiteness in South Africa with reference to its particularity as well. Kritzinger's work is deeply conscious of this. This is evident in his conscious choice not only to choose Black theologians as his primary interlocutors for critically describing whiteness, but to explicitly choose South African Black theologians. What we find in his description of whiteness, therefore, does reveal aspects of how whiteness is constructed globally (such as the relation to economic power), but it also reveals the particularities of South African whiteness (such as the particular way in which whiteness is tied to land and/or language) and it also highlights that whiteness in South Africa has changed over time (primarily in how whiteness is constructed in relation to the state).

His social description is rarely a uniquely Christian or theological description, but in an attempt to describe whiteness theologically it draws on the language of idolatry, which is described as 'a worship of the false gods of the system of oppression' (Richard, in Kritzinger 1988:281). In order to analyse whiteness in South Africa it is thus imperative to analyse the idols through which whiteness has been constructed. 
Through this he emphasises that theology is concerned with 'the whole of human reality' and 'attempts to ascertain the things that actually control the lives of people, in other words, the real "gods" to which people are devoted and bound' (Kritzinger 1988:284, emphasis in original).

Examples of the idols that he describes include the emphasis on 'state security' and the 'widespread, often unquestioning, support of white people for this security ideology' (Kritzinger 1988:291) as well as the belief that South Africa is a white country belonging to white people and that white people should have a religious willingness to even sacrifice their lives for this land (1988:287-290). Similarly the concepts of money and racial ideology are described as idols through which whiteness is constructed.

The description of whiteness as idolatry calls forth his theological and missiological response to whiteness, a call for change in the white community and the transformation of whiteness.

\section{Transforming whiteness}

The main focus of this article is the theology that is constructed when catching the boomerang of Black Theology and working out a liberating ministry to the white community. The title of Kritzinger's inaugural lecture was Studying religious communities as agents of change: An agenda for missiology (1995). The lecture developed his understanding of the role of Missiology as a discipline and the challenges facing theological education in South Africa. As an inaugural lecture it serves as a beacon of his view points and thinking, and I find this an appropriate overarching notion to correlate the various theological concepts that he relates to the problem of whiteness.

To understand his work we need to bear in mind that his doctoral studies were in Missiology and were an attempt to listen to Black Theology as a challenge to mission. He defines mission as 'that dimension of [a religious community's] existence which is aimed at making a difference to the world, at influencing or changing society in accordance with its religious ideals' (Kritzinger 1995:368). Whereas the one key aspect of Kritzinger's work is that it should be read as a response to and in solidarity with and to Black Theology, the other is that all of his work on whiteness should be read through the lens of seeking change.

The three theological categories that he employs in responding to whiteness are liberation, conversion and reevangelisation. Although these are obviously intertwined I will discuss his use of each separately.

\section{Liberating whiteness}

Liberation is the key theological lens running throughout Kritzinger's work, receiving more attention than either conversion or re-evangelisation.
Central to Kritzinger's reading of Black Theology is that apartheid has harmed white people (Kritzinger 1988:294). He writes that

[it] is one of the fundamental tenets of Black Theology that oppression dehumanises not only the oppressed but also the oppressors. By keeping black people in bondage, white people have imprisoned themselves and distorted their own humanity. (p. 202)

A liberating white theology, therefore, should emphasise that humanisation includes working for the humanity of white people, and such a theology might then also be described as a deeply pastoral theology. It is important to note this pastoral dimension, because the assumption might be made too easily that a theology focusing on the responsibility of the oppressors is merely guilt-inducing and focuses on identifying and persecuting perpetrators. Liberation then means that we also note that those who are white have been 'sinned against' (Kritzinger 1988:295) and, therefore, are in need of liberation. This conclusion then leaves us with the dual questions: What are white people being liberated from, and what are they being liberated for?

The description of how racism is harming white people does not get a full analysis in Kritzinger's work. We are left with only brief comments arguing that racism and apartheid harm white people by keeping them imprisoned in their intolerance and fear (Kritzinger 1988:295). This imprisonment, however, does become clearer in the extensive and repetitive description of what white people are liberated for.

Kritzinger's hope for white people is that they will become white Africans (Kritzinger 1988:203, 319-321; 1990b:63-65; 1994:10-12; 2008b:17-21), or perhaps a better description of this identity would be Euro-Africans. ${ }^{5}$ This statement should immediately make us aware of two possibilities that are being rejected: on the one hand that white people are Africans by merely having been born in Africa, and on the other hand that it is impossible for those who are white to ever be called African. Becoming African will require effort and may be difficult, but it is not impossible.

Becoming African would require change in white people. This change is described as the conversion from the idols mentioned above and as restitution and acceptance of the guidance and leadership of the African majority. The one aspect that Kritzinger emphasises most is the learning of languages. The lack of ability to speak an African language not only continues to cause separation and the inability of white South Africans to really understand black South Africans, but Kritzinger also uses this as a marker for how much still needs to be done. If white South Africans do not learn an additional African language (apart from Afrikaans), then their commitment to becoming Africans is called into question (Kritzinger 1991:110; 1994:11; 2001:263; 2008b:22).

5. Kritzinger seems to prefer using the term white Africans, but sometimes presents European Africans or Euro-Africans as alternatives (Kritzinger 1987:110; 2008b:17). 
Kritzinger also uses Hillbrow as an image of what we may become. Hillbrow is a notorious part of the inner-city of Johannesburg where, in the 1970s, segregation became increasingly difficult to enforce (Brown 2015). Drawing on Johannes Kerkorrel's well-known Afrikaans song 'Hillbrow', in which he refers to the variety of people found on the streets of Hillbrow (a vision that might have been an idealised portrayal of Hillbrow), Kritzinger uses this as a paradigm of a possible future. It is an unpredictable future, but it could be one where our life together contributes to a renewed sense of humanity (Kritzinger 1991:113-114; 1994:13-14).

It would not be saying too much to argue that becoming African functions eschatologically in Kritzinger's thinking. He argues that liberation is the key category in Black eschatology (Kritzinger 1987:15), and this emphasis on becoming African and Hillbrow as a vision of a possible future serve as markers for the liberation of white South Africans.

A liberating white theology, therefore, would work to assist white South Africans to truly become part of the Africa in which they live, or perhaps more accurately to make Africa part of who they are. In his own words,

[i]ndeed, the question is not how long we have been in Africa but whether Africa is in us, whether we identify with the people of Africa in a significant way. (Kritzinger 2008b:20)

Only this will liberate white South Africans from the fear and disconnection that racism created. This need amongst white South Africans to become more deeply connected to Africa and black South Africans is expressed, for example, by Antjie Krog's Begging to be black (2009) and Melissa Steyn's description of why she was motivated to work on whiteness: because she 'had never known to inhabit [her] land other than as some sort of psychological squatter' (Steyn 2001:xvi). This leaves us with two questions: firstly, is this a liberation that white South Africans truly long for (or even recognise as liberating), and, secondly, to what extent can such a longing for white liberation convince white South Africans to enter into the difficult task of conversion and being re-evangelised?

\section{Conversion}

Kritzinger describes conversion as consisting of two movements: the turning away from what is wrong and a turning towards a new possibility (Kritzinger 1988:180; 1990b:56). If whiteness is constructed around the idolatries of race, money, land and self-interest, then those whose identity is constituted by these idols are called to conversion.

Although whiteness is closely connected with Christianity, and historically in Africa particularly the white missionary calling African 'heathens' into a conversion away from idolatry, whiteness itself is here revealed as in need of conversion, even, or perhaps in particular, when it presents itself as 'Christian'. A liberating white theology, therefore, turns the gaze of Christian mission onto the white centre, which presents itself as the historic bastion of Christianity.
Although Kritzinger's initial development of a call to conversion preceded the publication of Peggy McIntosh's (1989) important essay on white privilege, his approach shares the general thrust of critical whiteness studies to focus on those racialised as white. Roger Haight (2007) has more recently argued against the rhetoric of white privilege as an attempt to enact change in white Americans. Although Haight agrees with such a description of whiteness, he argues that the call to dismantle white privilege ultimately fails, because there is no positive alternative to the negative of racism. Therefore, he suggests an emphasis on racial solidarity as the call to white people in response to racism.

Haight's essay illuminates this argument, since what he criticises is repeated in Kritzinger's call to conversion as well. The limit of Haight's approach, and where Kritzinger would differ, is best understood against the background of Steve Biko's critique of white liberals, which had a profound influence on Kritzinger's work. Biko argues that when non-racialism is placed in dialectical tension with apartheid, there is no clear synthesis, no vision of what society should become. Therefore, he argues for Black Consciousness as the dialectical opposite to white racism in order to work towards a true humanity (Biko 1973:39). Similarly we might argue that if racial solidarity is presented as the dialectical (in following Biko's use of the term) positive to racism then the synthesis remains unclear.

Kritzinger takes Biko's call for a true humanity as the synthesis, perhaps more appropriately as the eschatological vision, of a world in which racism is dismantled (Kritzinger 2008b:5-8). However, whereas Haight is doubtful of the language of white privilege, since it immediately puts white people on the defensive and, therefore, fails to initiate change, Kritzinger would argue that a failure to engage this critique, a failure to go through the razor of Black Consciousness, would mean that white people are not able to contribute to an anti-racist journey towards a true humanity.

The difference might perhaps be found in Haight's leading image of racism: the extreme and blatant racist police brutality in the 1963 civil rights protests. This image allows the possibility that racism can be perceived as something 'out there' that white people can join in opposing. However, Kritzinger's argument would be that no white South African, himself included, is left untainted. Although a critique of whiteness, therefore, might lead to disengagement by white people and a withdrawal into white enclaves, a movement towards a new humanity is not possible without thoroughly acknowledging and engaging this critique.

This conclusion leaves us with a question that is deeply ministerial and pastoral: How do we assist white Christians to go through this difficult process of engaging critical perspectives on whiteness, critical perspective on themselves? I will use the third notion in an attempt to answer this question. 


\section{Re-evangelising}

A third way in which Kritzinger develops his theological response to whiteness is around the notion of reevangelisation. Black Theology called for a re-evangelisation of black people, calling black people into self-acceptance, accepting themselves as created in the image of God (humanisation) and committing themselves to the struggle for justice (Kritzinger 1988:172-197). Here we notice Black Theology as having a deeply pastoral concern (pp. 173, 197). Similarly, the white church needs to be re-evangelised, implying 'that something went seriously wrong in the evangelisation of the white community until now' (Kritzinger 1991:107) and working towards 'awakening the white church to become an agent of liberating and constructive change' (p. 116). Amongst other things, Kritzinger suggests that this shift will concretely call for changes in white suburban life, particularly white people's relationship with domestic workers (p. 109), and that white theologians and preachers should start to hold up the contributions of black people as 'permanent living symbols of faith' to the white church (p. 111).

It is important to note that Kritzinger uses evangelisation as an activity focused on those who already profess to be Christian. In the late 1980s, he was explicit about the fact that our priority is not to evangelise the 'unreached', but to 'rereach the reached', including ourselves (Kritzinger 1987:23). ' $[R] \mathrm{e}$-evangelisation involves helping Christians to break with the unjust established order and to commit themselves to the creation of a new society' (emphasis in original, Kritzinger 1991:107). In a later argument he repeats that the church is good at pointing out the sins of society but needs to learn to reflect critically on itself (Kritzinger 2001:262).

Although the content of what Kritzinger believes white people need to do is not always exclusively Christian, the Christian faith does provide the motivation to work towards change, and the emphasis throughout his writings is on working for change in the church. The tension in his work is that the change in society is what he is concerned with as a liberation theologian, but the way in which he works for this as a liberation theologian is by working for change within the church in particular. One reason for this focus is his conviction that the church cannot call for change in society if it does not embody that change in its own life (Kritzinger 1991:107; 2001:262).

In Kritzinger's work as a white theologian responding to Black Theology, the responsibility he discerns for white theologians becoming conscious of racism in the church and conscious of their own whiteness and white racism is to actively call white Christians towards a changed identity. This is important for the current argument, because it reveals a distinct aspect of Kritzinger's contextual theology and, connected to this, a particular strategic decision on how to bring about change in a racist society. This leads us into the next section, which positions Kritzinger as a contextual theologian.

\section{Situating Kritzinger as a contextual theologian}

As a first step in critically analysing Kritzinger's proposed white theology, I will situate Kritzinger's white theology as a particular contextual theology. I will do this by referring to a number of distinctions made in analysing contextual theologies, ending with Bevans' classic Models of contextual theology as a tool for describing Kritzinger's work.

The first distinction concerns the statement that all theology is contextual (Pears 2009:1). Although this might be true in very broad and general terms it does not assist us in speaking about specific attempts at contextualisation (Botha 2010:182). In more general terms, Albert Nolan recently wrote on this issue: 'In a way all theology is contextual. The difference is between those who are aware of this and those who are not' (Ackermann 2014:11). This statement points out the first distinction when reflecting on contextual theology: the distinction between a general understanding of all theology as being contextual and 'theology which explicitly places the recognition of the contextual nature of theology at the forefront of the theological process' (Pears 2009:1) - what Bosch would describe as contextual theology proper (Bosch 2004:421). This concerns not only conscious awareness of the contextuality of our theology, but making this context an explicit starting point for our theological process.

From the argument thus far it should be clear that Kritzinger's work is consciously contextual. When referring to white theology such a distinction is of the utmost importance. It has become common to point out that what presents itself as 'theology proper', as theology without any marked contextuality or as a universalised theology, is often theology that is white, male and European (or North American). What is being criticised by Black Theology is then a contextual theology but not simply the mirror of Black Theology, and one important reason for this is the fact that such a theology remains unconscious and, therefore, uncritical of exactly how it is a particularly white, male and European theology. What Kritzinger develops is a theology that is conscious of whiteness, which is white in a critical sense, taking the description of Black Theology as primary source for its own self-reflection.

The danger of engaging in such a project should not be overlooked. The danger is not primarily found in the common fear that naming race would serve to reinscribe it in a socalled post-racial society. Rather, the danger repeatedly pointed out in whiteness studies, and also in a critical response to whiteness studies, is that shifting the gaze, albeit critical, onto whiteness may serve to recentre whiteness. Relating to contextual theology, the danger is that we might be led into the temptation of considering the perspective and experience of white people to be the starting point of our theology. Any attempt at developing a white theology that simply takes its own experience of being white as starting point would inevitably repeat such a mistake. Perkinson (2004:41), therefore, argues that 'any self-consciously white 
theology [which] takes itself seriously as white' has to speak from the self-same context as Black Theology. The context of white racism, which gives rise to Black Theology, is the context that should form the starting point of any anti-racist white theology. This point leads us to the second distinction.

Gustavo Guttierrez makes a broad distinction between two interlocutors of theology: the poor and the non-believer or, rather, the non-person and those 'under the sway of modernity'. Although liberation theology has developed through the commitment to the poor as the dialogue partner of theology, another stream of modern theology has responded to the challenge posed by the European Enlightenment and takes the non-believer as its primary dialogue partner (Guttiérrez 2001:21). Although Kritzinger is consciously speaking as a theologian of European descent, his primary dialogue partners in developing this theology are the poor and the non-person, which in the context of white racism are black South Africans.

Kritzinger's approach can then be described as a mission to the perceived centre, those places of power and privilege that also happen to be the historic centre of Christian mission, namely the white church of European descent and its Christians. Where shifts in the focus of mission towards the historic centres are involved, it usually fits more easily into Gutiérrez' second group, which entails focusing on the loss of power of the church in secularised societies and the challenge the church faces in this increasingly secularised society, the subsequent decrease in church attendance and the inevitable decreasing influence of the church (Christianity) in society. Taking Black Theology and black Christians as his primary interlocutors, Kritzinger's mission towards the white church has little if any concern with the challenge to the Christian faith posed by growing secularisation. Rather, the problem is the way in which white Christians are embedded in oppressive relationships.

A third possible distinction, which is at times made in reflection on the types of contextual theology, is between theologies focusing on the socio-economic context on the one hand and theologies focusing on the cultural context on the other hand. This can be seen, for example, in Justin Ukpong's distinction between indigenisation and socio-economic models followed by Bosch (2004:420) and repeated by, for example, Kristeen Kim (2004:48) or in Robert Schreiter's (1985:13) distinction between ethnographic and liberation approaches. Without engaging in a lengthy discussion of this common division, I point this out because the development of a consciously contextual white theology in the context of white racism, which Kritzinger attempts, breaks down such a distinct division.

Whilst Kritzinger's work is consciously developed from the tradition of, and in dialogue with, liberation theology, his analysis of whiteness makes it clear that socio-economic and racial oppression is structured through cultural aspects that need to be challenged and critiqued but also ultimately theologically reimagined. This endeavour calls for a cultural analysis of the white suburban lifestyle, the white suburban church (Kritzinger 1991:108) and white identity (Kritzinger 1994). This implies that his approach, which indeed mainly focuses on socio-economic questions, also points out that the required transformation includes the transformation, rather than the mere rejection, of white cultural identities - in his case in particular that of an Afrikaner (which he keeps in tension with a Christian, South African and African identity) (Kritzinger 1994:15).

With these distinctions made, I now proceed to discuss Kritzinger's white theology in dialogue with Bevans' Models of contextual theology. Already published in 1992, and revised and expanded in 2002, it remains one of the classic texts for providing an overview of the types of contextual theology (Pears 2009:2). However, Bevans is clear that the models should coexist, that our choice of how we develop a contextual theology should also be determined by the context and that there is no reason why we should be committed to only one of these models (Bevans 2002:139-140). Thus, rather than attempting to fit Kritzinger into one of these models, I use the models to illuminate and analyse the different aspects of his work. The three models that I find particularly appropriate for analysing Kritzinger's work are the praxis, countercultural and translation models.

It almost goes without saying that Kritzinger is a clear example of what Bevans describes as the praxis model. Most explicitly, Kritzinger has focused much of his own work on the further development of the praxis cycle of Holland and Henriot (Kritzinger 2002), ${ }^{6}$ but even preceding this work his inaugural lecture clearly emphasises this approach (Kritzinger 1995). Of particular concern for this argument, his work on whiteness is consciously embedded in what Bevans describes as one of the most visible examples of a praxis approach, liberation theology (in the form of Black Theology of liberation) ${ }^{7}$

As is clear at this point, Kritzinger's liberating white theology starts from a deep commitment to black South Africans and an anti-racist action, analyses the South African context and develops a theological response out of this commitment and analysis (compare Bevans 2002:76). This praxis approach to theology remains an important development in particular because, as Daniel Migliore (2014:18) argues, the ecumenical church has really only begun to learn from these methods. However even more true is that the implications of a theology that developed from a commitment to racial justice have received fairly little attention from those who embody privileged racial positions, those who are white. ${ }^{8}$ The important question that Kritzinger attempts to answer over the course of his work is: what does it mean for those who are white to commit to a liberating praxis for racial justice?

6.Also see how this seven-point praxis cycle is applied in response to a book edited by Piet Meiring (Kritzinger 2008a) and to the work of David Bosch (Kritzinger \& Saayman 2011).

7.Bevans actually feels the need to warn that his praxis approach should not be limited to liberation theology (Bevans 2002:73).

8. Harvey's (2014) recent historical overview of the response of the white church in North America to black calls for reparations again emphasised this point. 
Kritzinger asks this question as a theologian and, as indicated above, as a theologian committed to the church. A number of reasons might be considered for Kritzinger's choice to focus on the church and Christians for re-evangelisation. Apart from the point already mentioned, that the church cannot call for change in society if it does not embody that change in its own life, Kritzinger also believes that not only Christians but all people from all religions (and those who are not religious) should work towards the reconstruction of South Africa (Kritzinger 1991:112). His suggestion for the task of Missiology is also a focus on religious communities in general (not only Christian churches) as agents of change in society (Kritzinger 1995:368). As a theologian listening to Black Theology, he then views this task as a particular personal and ethical responsibility: he needs to work toward changing the white church to contrast a racist culture, assuming that others will do the same in their spheres of influence.

However, this white church is found in a white community and a racist society, and what he proposes for the white church contrasts with the white community in which it is found. I point this out because I think that it inevitably leads to his contextual theology taking on signs of a counter-cultural approach. The question is whether Christian symbols $^{9}$ can work for the transformation of white Christians against the logic of white culture. Many assumptions typical of a counter-cultural approach are not shared by Kritzinger. Most importantly, what he presents is emphatically not distinctly Christian, but part of a humanising agenda drawing from the well of Christian tradition to contribute to this agenda. However, in a world of inhumanity and with an approach that focuses on the church as an agent of change, it is inevitable that the church has to become a counter-cultural community when following Christ. Moreover, those white Christians who start to disrupt whiteness in their actions inevitably become (or hope to become) a contrast to white domination.

The translation model is often described as the most conservative approach to contextual theology (Pears 2009:24), or even not a true example of contextual theology (p. 25), since it continues to hold to the possibility of supracultural and eternal doctrinal truths (Bevans 2002:40). A critical description of this approach would be that what it considers to be 'core gospel truths' that must be translated is already a theology bound to a Western form of Christianity and already contextually determined.

Therefore, to introduce what I see as Kritzinger's relation to a translation model, some background is required. The struggle against apartheid caused a number of white Dutch Reformed Church theologians who opposed apartheid to join the black church. Kritzinger was one of them, and he has remained an active member of a black congregation and denomination ever since. Although this was a key factor

9.See, for example, his discussion of the Lord's Table as the Christian symbol most subversive of apartheid (Kritzinger 1991:114-116) and his own focus on how
Christian symbols can contribute to the humanisation of white people (Kritzinger 1990a:1). that enabled him to critically engage in the issue of whiteness, ${ }^{10}$ it inevitably led to an experience of alienation from the white community (Kritzinger 2008b:10). When he wrote about a ministry to the white church in 1991, he acknowledged that his argument was not based on day-to-day experiences in the white church and, therefore, he could not develop it into a practical program (Kritzinger 1991:107). A decade later he also pointed out that his own work on a liberating white theology had not made an impact on the white church, and partly attributed this to his own disconnection with the white church, which caused too little common ground for effective communication. However, he considered an effective programme of communication in the white church, we might say effective re-evangelisation, a prerequisite for effective antiracist programs in the church (Kritzinger 2001:248).

I point this out for two reasons. Firstly, because I think there is an important tension that we need to consider. The ability to critically reflect on whiteness requires some distance from the white community and being embedded in a different conversation. However, this might inevitably lead to a disconnection with the language of the community of origin, requiring an active process of reanalysis in order to effectively minister to the white community.

Secondly, this disconnected language and attempts at finding effective ways of communicating to the white church draw our attention to aspects of Bevans' translation model. However, Kritzinger's white theology turns the translation model in on itself by adopting patterns closely resembling a translation approach to contextual theology, but in a way that is distinctly outside-in. With this I mean that in the mission back to the white centre, the perspective of the poor, in Kritzinger's case found in Black Theology, that which would be considered a consciously contextual theology, is presented as the gospel, which needs to be translated for a white church that is not able to understand this language. The presence of God is found the poor, this is where God is revealed ${ }^{11}$ and Kritzinger, therefore, reads the call to conversion and the invitation to become Africans, which Black Theology presents to white South Africans, as a call from Christ himself (Kritzinger 1990a:8-9).

The task of the white missionary is then transformed into listening to the margins and translating this theology in such a way that those who are white in a racialised society can understand and respond to it. Again, this does not correspond to all of the technical definitions of a translation approach, but we can recognise a reversal at work, which in Kritzinger's contextual white theology reveals a form of translation that goes against the grain.

10.See his reflection on the influence of the Belydende Kring as a source of his commitment to a critical engagement of whiteness (Kritzinger 2001:243-248).

11.This statement draws on Bevans' description of revelation in the praxis model, where he contrasts the view of the translation model on revelation as consisting of where he contrasts the view of the translation model on revelation as consisting of
a supracontextual message with a praxis model that understands revelation 'as the a supracontextual message with a praxis model that understands revelation 'as the
presence of God in history ... in the experience of the poor and the marginalized' (Bevans 2002:75) 


\section{Conclusion}

William Jennings argues that Western theology has not yet begun to explore the depths of the influence of the colonialist moment on Western theology and continues 'to misunderstand the theological power of white and black identities' (2011:64). For Jennings the concern is with the deep theological mistake, which changed the way we imagine land and space, and he argues that the way forward, if there is a way forward, will involve several more conceptual steps before a future of communion might be envisioned' (p. 64). Jeorg Rieger has commented that although the colonialist mistakes of mission have been generally acknowledged (even while its deeper reasons might not have been addressed) 'considerably less awareness of the colonial mistakes of the theology of the same period' (2004:207) can be seen.

If this observation is correct it is perhaps not accidental that Black Theology gets its most consistent academic response from a white theologian in South Africa as a challenge to mission rather than to theology. Kritzinger's challenge to the broader field of theology in South Africa would then be whether other white theologians would be willing to take up the challenge of Black Theology for different theological questions.

Kritzinger's contribution towards a white theological response to Black Theology was focused primarily on turning a missiological gaze onto white South Africans. Liberation, conversion and evangelism provided the theological language for his attempt at finding a theology that could effect change among white South African Christians.

As the debate on whiteness continues to be developed into a more nuanced discourse, both in South Africa and elsewhere, in an interdisciplinary context and also within theology, it is important to remember the early prophets' attempts at this difficult task. In concluding her argument on 'what should white people do?', the North American philosopher Linda Alcoff (1998) argues that we need a commitment to the simultaneous work of

... acknowledgment of the historical legacy of white identity constructions in the persistent structures of inequality and exploitation, as well as a newly awakened memory of the many white traitors to white privilege who have struggled to contribute to the building of an inclusive human community ... retrieving from obscurity the history of white antiracism even while providing a detailed account of colonialism and its many cultural effects. (p. 25)

This article attempted to retrieve, if not from total obscurity then at least towards a more conscious analysis, one such sustained theological treachery to white privilege, a theology of white anti-racism. This is one small part of what is required of white theologians in the face of continued racism. Kritzinger's cannot be the last South African attempt at constructing such a white response to racism and the challenge of Black Theology.

\section{Acknowledgements}

This work is based on the research supported in part by the National Research Foundation of South Africa; The author acknowledges that opinions, findings and conclusions or recommendations expressed in this publication which is generated by the NRF supported research are that of the author, and the NRF accepts no liability whatsoever in this regard.

\section{Competing interests}

The author declares that he has no financial or personal relationships that may have inappropriately influenced him in writing this article.

\section{References}

Ackermann, D.M., 2014, Surprised by the man on the borrowed donkey, Lux Verbi, Cape Town.

Alcoff, L.M., 1998, 'What should white people do?', Hypatia 13(3), 6-26. http://dx.doi. org/10.1111/j.1527-2001.1998.tb01367.x

Banda, Z.J., 2009, 'Solidarity with victims: An appraisal of JNJ (Klippies) Kritzinger's contribution to the praxis of liberation theology', Missionalia 37(3), 111-124.

Beaudoin, T. \& Turpin, K., 2014, 'White practical theology', in K.A. Cahalan \& G.S. Mikoski (eds.), Opening the field of practical theology. An introduction, pp. 251-269, Rowman \& Littlefield, Plymouth.

Bevans, S.B., 2002, Models of contextual theology, Orbis Books, New York, NY.

Biko, S., 1973, 'Black consciousness and the quest for a true humanity', in B. Moore (ed.), Black theology: The South African voice, pp. 36-47, C. Hurst \& Company, London.

Bosch, D.J., 2004, Transforming mission, Orbis, New York, NY.

Botha, N., 2010, 'If everything is contextual, nothing is contextualisation: historical methodological and epistemological perspectives', Missionalia $38(2)$ 181-196.

Brown, R.L., 2015, South Africa's tower of dreams, viewed 10 May 2015, from http:// roadsandkingdoms.com/2015/south-africas-tower-of-dreams/

Budden, C., 2009, Following Jesus in invaded space: Doing theology on aboriginal land, Pickwick Publications, Eugene, OR.

Cassidy, L.M. \& Mikulich, A. (eds.), 2007, Interrupting white privilege: Catholic theologians break the silence, Orbis Books, New York, NY.

Cone, J.H., 2012, 'The challenge of race: A theological reflection', in M.Y. Riggs \& J.S. Logan (eds.), Ethics that matters: African, Caribbean, and African American sources, pp. 77-98, Fortress Press, Minneapolis, MN.

Garner, S., 2007, Whiteness: An introduction, Routledge, New York, NY.

Guttiérrez, G., 2001, A theology of liberation, SCM Press, London.

Haight, R., 2007, 'The dysfunctional rhetoric of "White Privilege" and the need for racial solidarity', in L.M. Cassidy \& A. Mikulich (eds.), Interrupting white privilege. Catholic theologians break the silence, pp. 85-94, Orbis Books, New York, NY

Harvey, J., Case, K.A. \& Gorsline, R.H. (eds.), 2004, Disrupting white supremacy from within, Pilgrim Press, Cleveland, $\mathrm{OH}$.

Harvey, J., 2014, Dear white Christians. For those still longing for racial reconcialiation Eerdmans, Grand Rapids, MI.

Jennings, W.J., 2011, The Christian imagination: Theology and the origins of race, Yale University Press, London.

Kim, K., 2004, 'India', in J. Parratt (ed.), An introduction to third world theologies, pp. 44-73, Cambridge University Press, Cambridge. http://dx.doi.org/10.1017/ CB09780511801587.003

Kritzinger, J.N.J., 1987, 'Black eschatology and Christian mission', Missionalia 15(1), $14-27$.

Kritzinger, J.N.J., 1988, 'Black Theology: A challenge to mission', DTh thesis, Dept. of Missiology, University of South Africa.

Kritzinger, J.N.J., 1990a, A theological perspective on white liberation, Centre for Contextual Hermeneutics, University of Stellenbosch.

Kritzinger, J.N.J., 1990b, 'Teologie vir wit bevryding', in M. Hofmeyr, J.N.J. Kritzinger \& W. Saayman (reds.), Wit Afrikane? ' $n$ Gesprek met Nico Smith, bl. 54-66, Taurus, Kaapstad.

Kritzinger, J.N.J., 1991, 'Re-evangelising the white church', Journal of Theology for Southern Africa 76(September), 106-116.

Kritzinger, J.N.J., 1994, 'Identiteitskrisisse in die transformasieproses', in Die Christen in die branding van die transformasieproses in Suid Afrika, pp. 1-16, Instituut vir Reformatoriese Studie, Potchefstroom. 
Kritzinger, J.N.J., 1995, 'Studying religious communities as agents of change: An agenda for missiology', Missionalia 23(3), 366-396.

Kritzinger, J.N.J., 2001, 'Becoming aware of racism in the church', in M.T. Speckman \& L.T. Kaufmann (eds.), Towards an agenda for contextual theology, pp. 231-275, Cluster Publications, Pietermaritzburg.

Kritzinger, J.N.J., 2002, 'A question of mission - A mission of questions', Missionalia 30(1), 144-173.

Kritzinger, J.N.J., 2008a, 'Faith to faith - Missiology as encounterology', Verbum et Ecclesia 29(3), 764-790. http://dx.doi.org/10.4102/ve.v29i3.31

Kritzinger, J.N.J., 2008b, Liberating whiteness: Engaging with the anti-racist dialectics of Steve Biko, viewed 15 March 2013, http://uir.unisa.ac.za/bitstream/ handle/10500/4326/Kritzinger.pdf

Kritzinger, J.N.J. \& Saayman, W., 2011, David J. Bosch. Prophetic integrity, cruciform praxis, Cluster Publications, Dorpspruit.

Krog, A., 2009, Begging to be black, Random House Struik, Cape Town.

McIntosh, P., 1989, White privilege: Unpacking the invisible knapsack, viewed 06 November 2011, from http://www.isr.umich.edu/home/diversity/resources/ white-privilege.pdf

Migliore, D.L., 2014, Faith seeking understanding. An introduction to Christian theology, William B. Eerdmans, Grand Rapids, MI.
Nel, R.W., 2009, “"Finding a place under the African sun": The search for new identities in post-colonial (Southern) Africa evidenced in students' writing in the Missiology
course, Christian Action for Anti-Racism and Reconciliation at Unisa', Missionalia 37(3), 138-152.

Pears, A., 2009, Doing contextual theology, Routledge, New York, NY.

Perkinson, J.W., 2004, White theology: Outing supremacy in modernity, Pelgrave Macmillan, New York, NY.

Rieger, J., 2004, 'Theology and mission between neocolonialism and postcolonialism', Mission Studies 21(1), 201-227. http://dx.doi.org/10.1163/1573383042653677

Saayman, W., 2009, 'Personal reflections: Klippies Kritzinger as I know him', Missionalia $37(3), 12-23$.

Schreiter, R.J., 1985, Constructing local theologies, Orbis Books, Maryknoll, NY.

Steyn, M., 2001, Whiteness just isn't what it used to be, State University of New York Press, New York, NY.

Tenai, N.K., 2010, 'The poor and the public: An exploration of synergies between Black Theology and public theologies', D.Th thesis, Faculty of Theology, University of Stellenbosch.

Vellem, V.S., 2007, 'The symbol of liberation in South African public life: A Black Theological perspective', D.Th thesis, Faculty of Theology, University of Pretoria. 